University of Nebraska - Lincoln

DigitalCommons@University of Nebraska - Lincoln

8-2-2007

\title{
Increase in Near-Surface Atmospheric Moisture Content due to Land Use Changes: Evidence from the Observed Dewpoint Temperature Data
}

\author{
Rezaul Mamood \\ University of Nebraska - Lincoln, rmahmood2@unl.edu \\ Kenneth G. Hubbard \\ University of Nebraska-Lincoln, khubbard1@unl.edu \\ Ronnie D. Leeper \\ Western Kentucky University \\ Stuart A. Foster \\ Western Kentucky University
}

Follow this and additional works at: https://digitalcommons.unl.edu/natrespapers

Part of the Natural Resources and Conservation Commons, Natural Resources Management and Policy Commons, and the Other Environmental Sciences Commons

Mamood, Rezaul; Hubbard, Kenneth G.; Leeper, Ronnie D.; and Foster, Stuart A., "Increase in Near-Surface Atmospheric Moisture Content due to Land Use Changes: Evidence from the Observed Dewpoint Temperature Data" (2007). Papers in Natural Resources. 1055.

https://digitalcommons.unl.edu/natrespapers/1055

This Article is brought to you for free and open access by the Natural Resources, School of at DigitalCommons@University of Nebraska - Lincoln. It has been accepted for inclusion in Papers in Natural Resources by an authorized administrator of DigitalCommons@University of Nebraska - Lincoln. 


\title{
NOTES AND CORRESPONDENCE
}

\section{Increase in Near-Surface Atmospheric Moisture Content due to Land Use Changes: Evidence from the Observed Dewpoint Temperature Data}

\author{
ReZAul MAHMOOD \\ Department of Geography and Geology, and Kentucky Climate Center, Western Kentucky University, Bowling Green, Kentucky
}

KenNeth G. HubBard

High Plains Regional Climate Center, and School of Natural Resources, University of Nebraska-Lincoln, Lincoln, Nebraska

\author{
Ronnie D. Leeper And Stuart A. Foster
}

Department of Geography and Geology, and Kentucky Climate Center, Western Kentucky University, Bowling Green, Kentucky

(Manuscript received 2 October 2006, in final form 2 August 2007)

\begin{abstract}
Land use change can significantly affect root zone soil moisture, surface energy balance, and near-surface atmospheric temperature and moisture content. During the second half of the twentieth century, portions of the North American Great Plains have experienced extensive introduction of irrigated agriculture. It is expected that land use change from natural grass to irrigated land use would significantly increase nearsurface atmospheric moisture content. Modeling studies have already shown an enhanced rate of evapotranspiration from the irrigated areas. The present study analyzes observed dewpoint temperature $\left(T_{d}\right)$ to assess the affect of irrigated land use on near-surface atmospheric moisture content. This investigation provides a unique opportunity to use long-term (1982-2003) mesoscale $T_{d}$ data from the Automated Weather Data Network of the high plains. Long-term daily $T_{d}$ data from 6 nonirrigated and 11 irrigated locations have been analyzed. Daily time series were developed from the hourly data. The length of time series was the primary factor in selection of these stations. Results suggest increase in growing-season $T_{d}$ over irrigated areas. For example, average growing-season $T_{d}$ due to irrigation can be up to $1.56^{\circ} \mathrm{C}$ higher relative to nonirrigated land uses. It is also found that $T_{d}$ for individual growing-season month at irrigated locations can be increased up to $2.17^{\circ} \mathrm{C}$ by irrigation. Based on the results, it is concluded that the land use change in the Great Plains has modified near-surface moistness.
\end{abstract}

\section{Introduction}

Local and regional-scale land use change can profoundly affect the hydroclimatic cycle at these scales. A significant number of modeled (e.g., Bonan 1997; Chase et al. 1999; Eastman et al. 2001) and several observed data-based studies have (e.g., Bonan 2001; Kalnay and Cai 2004 McPherson et al. 2004) demonstrated potential and actual impacts of land surface modification on near-surface hydroclimatology and hydrometeorology.

Corresponding author address: Rezaul Mahmood, Dept. of Geography and Geology, and Kentucky Climate Center, Western Kentucky University, Bowling Green, KY 42101.

E-mail: rezaul.mahmood@wku.edu
Conversion of nonirrigated areas to irrigated land use results in more energy being partitioned into latent heat rather than sensible heat. This type of land use change and modification of energy balance also results in reduced long-term mean daily maximum temperatures. To support this notion, Mahmood and Hubbard (2002), Adegoke et al. (2003), and Mahmood et al. (2001) conducted modeling studies in the northern Great Plains and demonstrated that land use change would significantly modify near-surface hydrology and energy balance. For example, simulations suggested that at McCook, Nebraska, evapotranspiration (ET) for irrigated maize is nearly $36 \%$ higher than for natural grass (Mahmood and Hubbard 2002). It is $34 \%$ higher relative to rain-fed maize (Mahmood and Hubbard 2002). Sub- 
sequently, Mahmood et al. (2002, 2004, 2008, manuscript submitted to Climatic Change) demonstrated, with observed data, that these land use changes resulted in the modification of long-term temperature. From twentieth-century observed data taken from irrigated and nonirrigated locations it was found that mean maximum temperature during the growing season was decreasing over irrigated areas.

In light of these results and to more directly verify the above findings, observed dewpoint temperature $\left(T_{d}\right)$ data from the irrigated and nonirrigated locations across Nebraska are analyzed. This investigation provides a quantitative baseline, derived from observed data, for studying climate- and seasonal-scale impacts of land use with particular focus on the boundary layer atmospheric moisture. Because of conversion from nonirrigated land use to irrigated cropland, it is expected that near-surface atmospheric moisture content will increase during the growing season. This is the primary motivation for analyzing $T_{d}$ data.

The source of the $T_{d}$ data is the Automated Weather Data Network (AWDN) of the northern Great Plains (NGP) (www.hprcc.unl.edu). This is the oldest mesoscale network of the United States, operated and maintained by the High Plains Regional Climate Center (HPRCC). The dewpoint $T_{d}$ is calculated from relative humidity (RH) data. Teten's equation (Murray 1967) was used to obtain saturation vapor pressure. Subsequently, the network calculates $T_{d}$ using the Allen et al. (1994) method. Average daily $T_{d}$ is calculated from the hourly $T_{d}$. Before 1991 the relative humidity sensor (model) RH207 of Campbell Scientific (Logan, Utah) was used, while Vaisala probes of Campbell Scientific have been used afterward. Tests show that these two instruments agree within $1{ }^{\circ} \mathrm{C}$. Note that the $\mathrm{RH}$ sensors are part of air temperature sensing instrumentation and calibrated once a year between spring and summer. A quality control (QC) procedure is applied daily to ensure high quality of data (www.hprcc.unl.edu). Any discrepancy in the data is flagged by this QC program and the network technician subsequently makes site visits to address the noted problem. Further discussion on data is provided in section 2. This research did not involve analyses of maximum, minimum, and mean temperatures for various time scales to avoid redundancy with Mahmood et al. (2002, 2004, 2008, manuscript submitted to Climatic Change).

As indicated above, this study focuses on the North American Great Plains. This and its adjacent regions experienced a remarkable land use change over the last 150 yr. Waisanen and Bliss (2002) found that in 1850 and in $19404.70 \%$ and $47.4 \%$, respectively, of total land area of the Great Plains and the Midwest were under

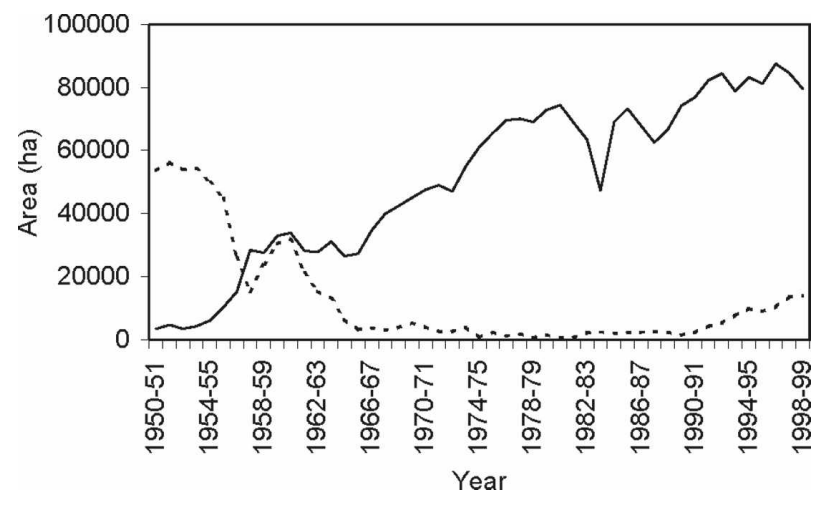

FIG. 1. Land use change in York, NE. Broken and unbroken lines represent total area of nonirrigated and irrigated corn land use, respectively. (Source: Mahmood and Hubbard 2002.)

"improved farm" or "crop lands" categories. Mahmood and Hubbard (2002) found that in some areas more than $80 \%$ of the land use has changed from nonirrigated to irrigated agriculture. It was found that in York, Nebraska, irrigated corn hectares changed from 3500 to 87000 from 1950-51 to 1995-96 (Fig. 1). Thus, the total change in irrigated land area was nearly 25 -fold from the 1950 s to the 1990s. These widespread changes made it imperative that their impacts on near-surface atmospheric conditions were investigated.

Recently, Sandstrom et al. (2004) and McPherson et al. (2004) investigated potential impacts of land use on $T_{d}$ at climatic and meteorological time scales, respectively. The present study is both different and complementary to these two studies for a number of reasons. First, Sandstrom et al. (2004) did not differentiate between irrigated and nonirrigated land use or agriculture. Mahmood and Hubbard (2002) demonstrated that difference of ET between nonirrigated corn and naturally grown grass in the NGP was relatively small. Hence, it is critical that the difference between irrigated and nonirrigated land use receives attention. Second, Sandstrom et al. (2004) used long-term $T_{d}$ data (1949 to 2000) from the first-order stations to determine impacts of the land use. Many of these stations were located at airports. In our study, mesoscale meteorological stations are surrounded either by irrigated or nonirrigated land use. Therefore, this study used more representative measurements of $T_{d}$ to determine the impacts of land use change.

There are a number of differences between the present study and that of McPherson et al. (2004). First, McPherson et al. (2004) used an 8-yr (1994-2001) time series for a number of stations that are part of the Oklahoma Mesonet. In this study, similar mesoscale datasets for Nebraska in which length of time series is up to 22 yr (1982-2003) are used. The present investigation did 


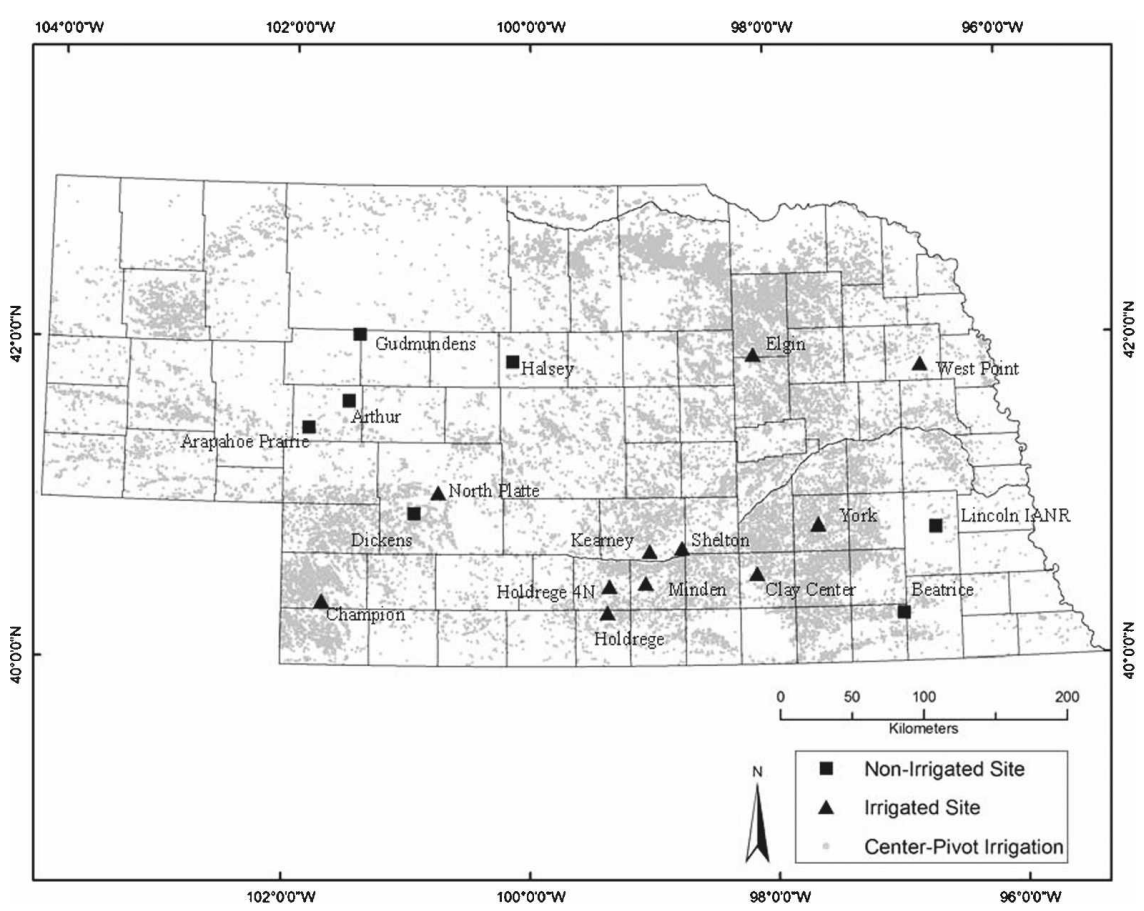

FIG. 2. Location of selected automated weather observing stations and irrigation in Nebraska.

not use any time series that started after 1996 except for York (1997-2003). Hence, the much longer time series used in this study. Second, McPherson et al. (2004) investigated impacts of nonirrigated winter wheat land use and surrounding naturally grown grasslands while this study focuses on irrigated and nonirrigated land use. The present study will show $T_{d}$ differences are much greater between irrigated and nonirrigated land use relative to two adjacent rainfed land uses with different vegetation cover (wheat and natural grass). This, in fact, verifies the findings of Mahmood and Hubbard (2002).

The following sections present discussions on study region, data, methods, results, and concluding remarks.

\section{Study area, data, and methods}

Geographically Nebraska is located near the center of the North American Great Plains. A large section of Nebraska's land use is dominated by agricultural activities including irrigated and nonirrigated. Obviously, one of the spectacular features of Nebraska's agriculture is the extensive and widespread adoption of irrigation (Fig. 2). This reality, along with availability of high-quality observed data, warranted and provided an opportunity to investigate impacts of land use change on near-surface atmospheric moisture.

This study analyzed long-term $T_{d}$ data during the growing season (May-September) from 11 irrigated and 6 nonirrigated sites (Fig. 2 and Table 1) in $\mathrm{Ne}-$ braska. The 11 irrigated locations include Champion, Clay Center, Elgin, Holdrege, Holdrege 4n, Kearney, Minden, North Platte, Shelton, West Point, and York. Nonirrigated locations include Arapahoe Prairie, Arthur, Beatrice, Gudmundsens, Lincoln IANR, and Halsey (Fig. 2). The selection criteria of these stations included length of the time series and ability to represent nonirrigated or irrigated land use. As noted above, data were collected, quality controlled, archived by the HPRCC. The length of the time series is up to $22 \mathrm{yr}$ (1982-2003). A digital dataset was also used to verify the surrounding land uses for each location. In addition, researchers at the University of Nebraska-Lincoln have developed a dataset and map of center pivot irrigation for Nebraska (UNL 2000). This publication was also consulted for determination of irrigated and nonirrigated locations.

To establish the impacts of land use change, first, mean monthly $T_{d}$ for nonirrigated and irrigated locations was calculated. Subsequently, we focused on months of May through September (growing season). It is well known that precipitation and atmospheric moisture decreases from east to west in the North American Great Plains. Based on this understanding, the present study developed regression relationships (cf. Geerts 
TABLE 1. List of selected AWDN stations and associated land uses for pairwise comparison.

\begin{tabular}{|c|c|c|c|c|}
\hline Location & Lat & Lon & Land use & Length of time series \\
\hline Champion & $40^{\circ} 24^{\prime}$ & $-101^{\circ} 43^{\prime}$ & Irrigated & 1 Jan 1982-31 Dec 2003 \\
\hline Clay Center & $40^{\circ} 34^{\prime}$ & $-98^{\circ} 08^{\prime}$ & Irrigated & 1 Jan 1983-31 Dec 2003 \\
\hline Elgin & $41^{\circ} 56^{\prime}$ & $-98^{\circ} 11^{\prime}$ & Irrigated & 1 Jan 1998-31 Dec 2003 \\
\hline Holdrege & $40^{\circ} 20^{\prime}$ & $-99^{\circ} 22^{\prime}$ & Irrigated & 1 Jan 1989-31 Dec 2003 \\
\hline Holdrege $4 n$ & $40^{\circ} 30^{\prime}$ & $-99^{\circ} 21^{\prime}$ & Irrigated & 1 Jan 1996-31 Dec 2003 \\
\hline Kearney & $40^{\circ} 43^{\prime}$ & $-99^{\circ} 01^{\prime}$ & Irrigated & 1 Jan 1994-31 Dec 2003 \\
\hline Minden & $40^{\circ} 31^{\prime}$ & $-99^{\circ} 01^{\prime}$ & Irrigated & 1 Jan 1996-31 Dec 2003 \\
\hline North Platte & $41^{\circ} 05^{\prime}$ & $-100^{\circ} 46^{\prime}$ & Irrigated & 1 Jan 1983-31 Dec 2003 \\
\hline Shelton & $40^{\circ} 44^{\prime}$ & $-98^{\circ} 45^{\prime}$ & Irrigated & 1 Jan 1991-31 Dec 2003 \\
\hline West Point & $41^{\circ} 51^{\prime}$ & $-96^{\circ} 44^{\prime}$ & Irrigated & 1 Jan 1983-31 Dec 2003 \\
\hline York & $40^{\circ} 52^{\prime}$ & $-97^{\circ} 37^{\prime}$ & Irrigated & 1 Jan 1997-31 Dec 2003 \\
\hline Arapahoe Prairie & $41^{\circ} 29^{\prime}$ & $-101^{\circ} 51^{\prime}$ & Nonirrigated & 1 Jan 1988-31 Dec 2003 \\
\hline Arthur & $41^{\circ} 39^{\prime}$ & $-101^{\circ} 31^{\prime}$ & Nonirrigated & 1 Jan 1983-31 Dec 2003 \\
\hline Beatrice & $40^{\circ} 18^{\prime}$ & $-96^{\circ} 5^{\prime}$ & Nonirrigated & 1 Jan 1990-31 Dec 2003 \\
\hline Gudmundsens & $42^{\circ} 04^{\prime}$ & $-101^{\circ} 26^{\prime}$ & Nonirrigated & 1 Jan 1983-31 Dec 2003 \\
\hline Lincoln IANR & $40^{\circ} 50^{\prime}$ & $-96^{\circ} 39^{\prime}$ & Nonirrigated & 1 Jan 1987-31 Dec 2003 \\
\hline Halsey & $41^{\circ} 54^{\prime}$ & $-100^{\circ} 09^{\prime}$ & Nonirrigated & 1 Jan 1994-31 Dec 2003 \\
\hline
\end{tabular}

2002) for each month of the year where $T_{d}$ changes in nonirrigated locations as a function of longitude (Table 2 and Fig. 3). The underlying assumption for these regression analyses is that nonirrigated locations represent pre-settlement land uses and natural near-surface moisture content. Subsequently, these regression equations were applied to $T_{d}$ data from irrigated locations for each month of the growing season (May-September) and adjustment to these data were completed. The near-surface atmospheric moistness under nonirrigated condition (preirrigation) is represented by adjusted $T_{d}$ data (Fig. 4). The difference between observed $T_{d}$ from irrigated locations and the adjusted $T_{d}$ (observed adjusted $T_{d}$ ) from these locations represent impacts of irrigation (Fig. 5a). In the following text, this difference will be referred as to $T_{\mathrm{d} \text {-obs-adj. }}$

\section{Results}

Figures 5a-e present $T_{\text {d-obs-adj }}$ for irrigated locations for May-September. It is quite clear that 8 of 11 irrigated locations experience higher $T_{d}$ after land use is modified. In May $T_{\text {d-obs-adj }}$ increases from 0.5 (Kearny) to $1.32^{\circ} \mathrm{C}$ (North Platte) (Fig. 5a). In June, July, August, and September these increases range from $0.24^{\circ}$

TABLE 2. The regression equations showing relationships between longitude (independent variable) and $T_{d}$ from nonirrigated sites.

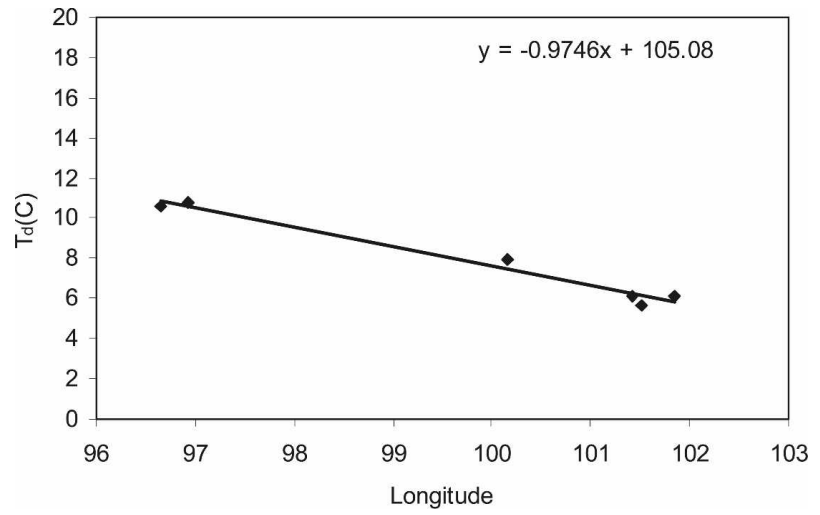

FIG. 3. Regression relationship between dewpoint temperature of nonirrigated sites and longitude for the month of May. Similar relationships are developed for each of the growing-season months (shown in Table 2).

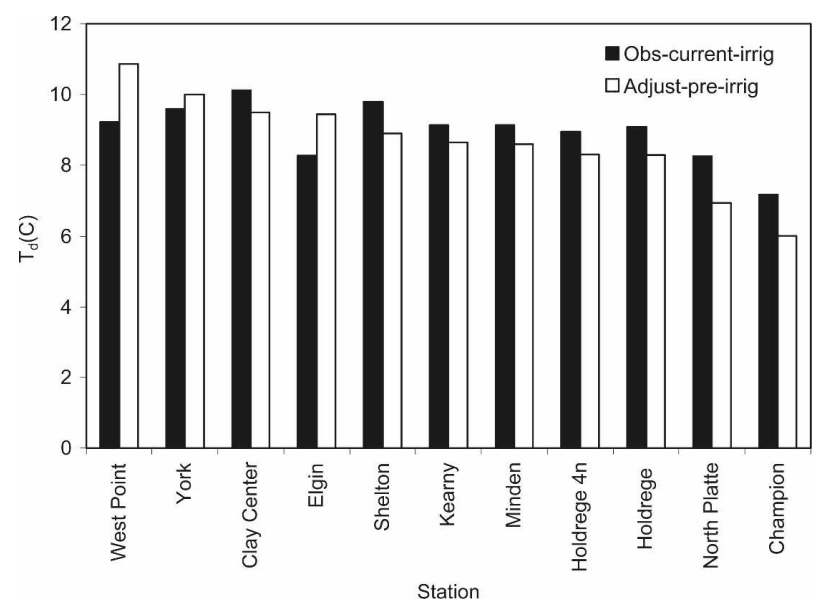

FIG. 4. Observed and adjusted $T_{d}$ for irrigated locations for the month of May. Observed $T_{d}$ for irrigated locations are adjusted to estimate $T_{d}$ for nonirrigated conditions. 
(a)

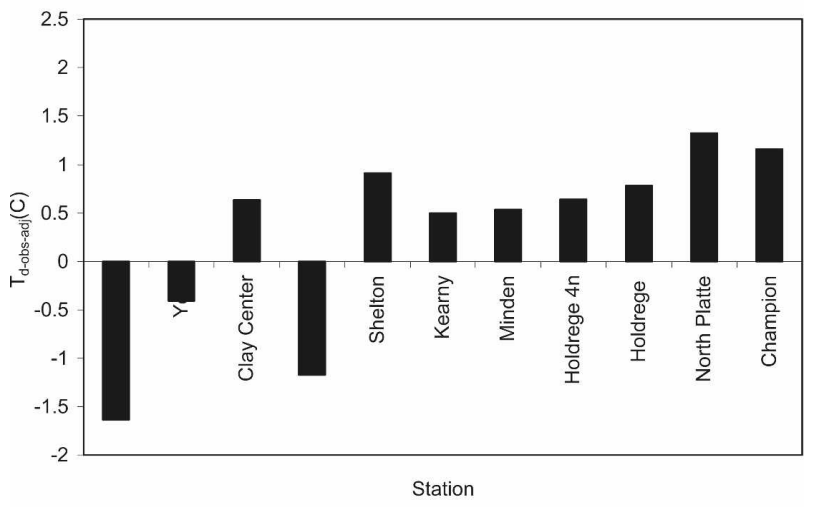

(d)

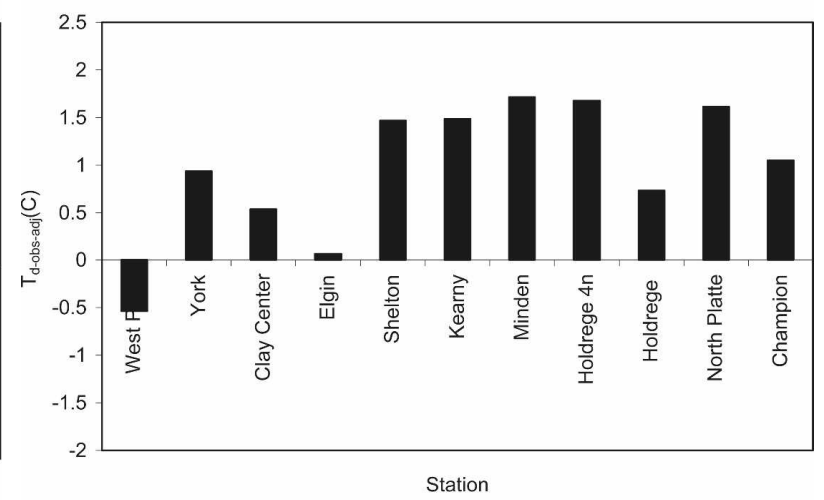

(e)

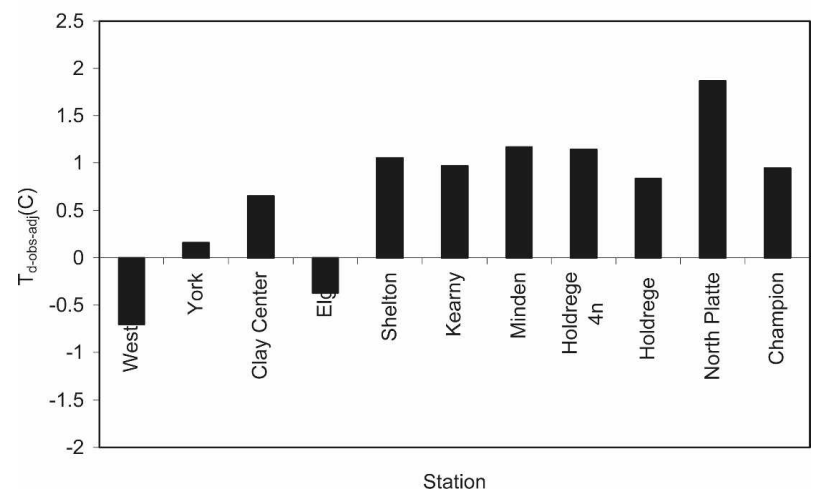

(b)

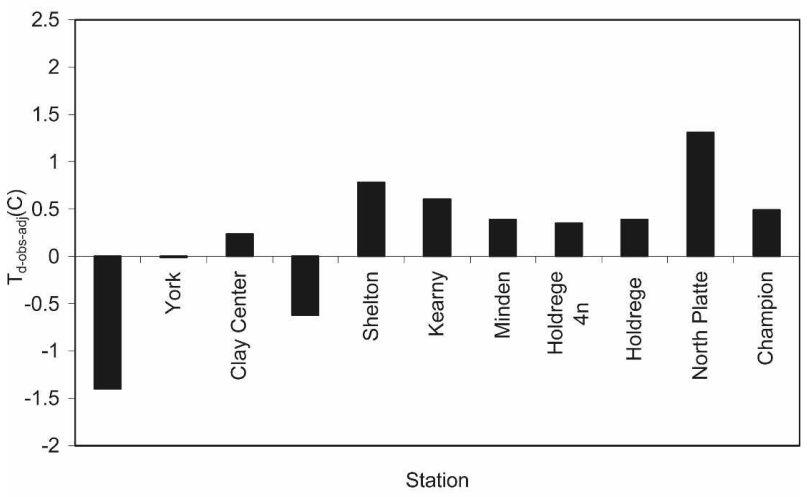

(c)

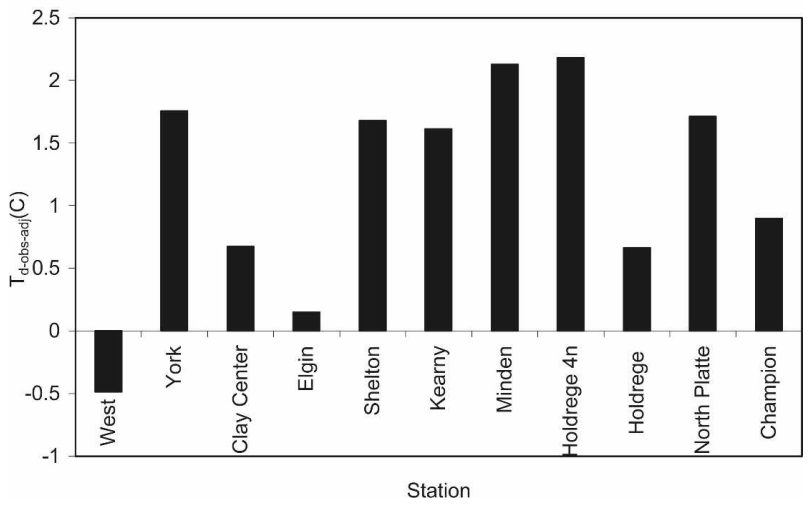

FIG. 5. Difference between observed and adjusted $T_{d}$ for irrigated locations. Positive values indicate increase of $T_{d}$ due to irrigation: (a) May, (b) June, (c) July, (d) August, and (e) September. Decreasing values in difference also suggest impacts of irrigation with progression of season, when looking at (a)-(e) in sequence.
(Clay Center) to $1.30^{\circ}$ (North Platte), $0.14^{\circ}$ (Elgin) to 2.17 (Holdrege 4n), $0.06^{\circ}$ (Elgin) to $1.71^{\circ}$ (Minden), and $0.15^{\circ}$ (York) to $1.86^{\circ} \mathrm{C}$ (North Platte), respectively (Figs. 5b-e). Hence, North Platte, North Platte, Holdrege $4 n$, Minden, and North Platte record the highest changes in $T_{d}$ for May, June, July, August, and September, respectively.

In addition, it is also found that North Platte most consistently records irrigation impacted higher $T_{d}$ (greater than $1^{\circ} \mathrm{C} T_{\text {d-obs-adj }}$ ) (Figs. 5a-e). The range of irrigation impacted increase for the growing-season months for North Platte is $1.30^{\circ}$ to $1.86^{\circ} \mathrm{C}$. Overall, for irrigated locations, month of July shows largest increase in $T_{\text {d-obs-adj }}$. It is suggested by the authors that this increase occurs when plants attain their peak growth stage and water demand and subsequent irrigation reaches the maximum. All irrigated locations suggest higher increase in $T_{d}$ and resulting greater $T_{\text {d-obs-adj }}$ as 
(a)

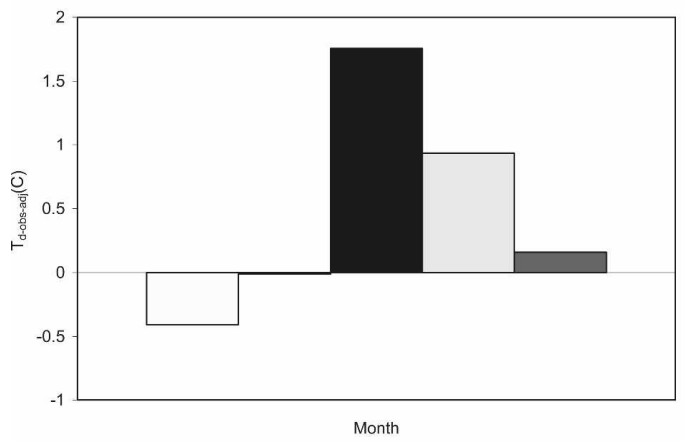

(b)

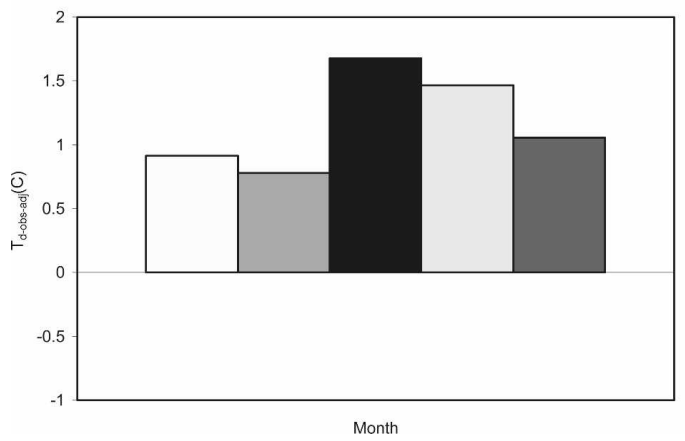

FIG. 6. Difference between observed and adjusted $T_{d}$ for irrigated locations during growing-season months: (a) York and (b) Shelton. It is evident that impacts of irrigation increase with the progression of season and decrease toward the harvesting period.

growing season peaks during July-August. The following months experience decrease as plants mature and harvesting season approaches when plant water requirement and irrigation also gradually declines (Figs. 6a,b).

During the growing season, irrigated York shows the largest increase in $T_{d}: T_{\text {d-obs-adj }}$ changed from $-0.40^{\circ}$ (May) to $+1.75^{\circ} \mathrm{C}$ (July) and hence reported $2.15^{\circ} \mathrm{C}$ increase (Fig. 7). Holdrege 4n, Minden, West Point, and Kearny also records notable increase in $T_{d}$ with the progress of the growing season. These increases are $1.83^{\circ}, 1.36^{\circ}, 1.15^{\circ}$, and $1.12^{\circ} \mathrm{C}$, respectively (Fig. 7). The smallest increase $\left(0.41^{\circ} \mathrm{C}\right)$ is reported for Clay Center (Fig. 7).

Mean-seasonal-irrigation-influenced $T_{d}$ increase is also calculated from monthly observed and adjusted data. In this case, 9 of 11 stations show irrigation influenced rise in growing-season $T_{d}$ and they range between $0.48^{\circ}$ and $1.56^{\circ} \mathrm{C}$ (Fig. 8). Figures 5a-e and 8 present $T_{\text {d-obs-adj }}$ where stations from left to right are from east to west. The figures indicate that, generally, irrigation-impacted $T_{\mathrm{d} \text {-obs-adj }}$ (thus $T_{d}$ ) rise is greater in the drier westerly located stations compared to relatively naturally moist eastern stations. The authors suggest that potentially greater application of irrigation

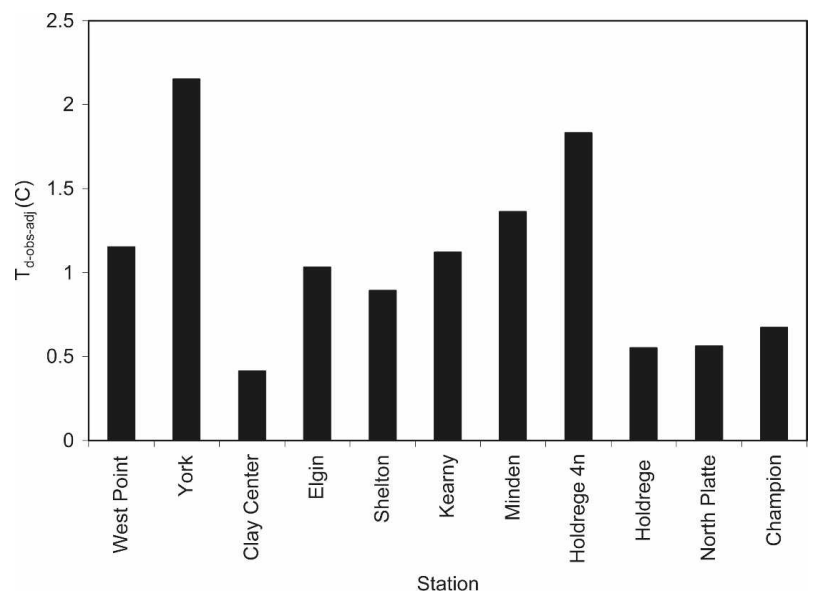

FIG. 7. The difference of the highest and the lowest mean monthly observed minus adjusted $T_{d}$ during the growing season. These estimates imply changes in impacts of irrigation with the progression of season when plant water demand also modifies.

water in the drier west may have resulted in this type of change $T_{d}$ distribution. However, further study is needed for conclusively determine the cause(s).

\section{Final remarks}

This study provides further evidence and verification of land use change and its impact on near-surface atmospheric moisture state using observed data. The results clearly show irrigated areas recorded much higher $T_{d}$ relative to preirrigation land use, particularly during the growing season when water applications are most frequent. Analyses of monthly data suggest that the difference of $T_{d}$ between irrigated and preirrigated land use $\left(T_{\mathrm{d} \text {-obs-adj }}\right)$ reaches its maximum during the

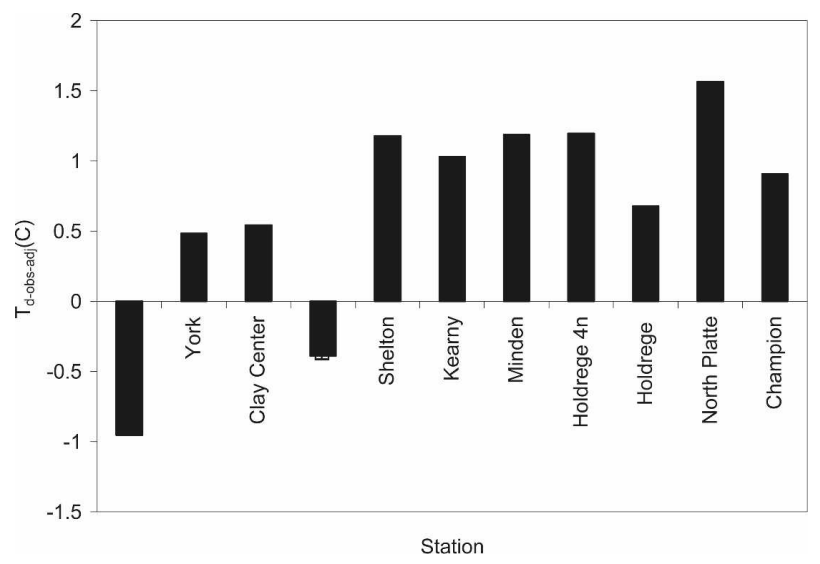

FIG. 8. Mean growing-season difference between observed and adjusted $T_{d}$ for irrigated locations. Positive values indicate increase of $T_{d}$ due to irrigation. 
months of July and August. These are the months of maximum growth and irrigation demand.

In the past, analyses of twentieth-century U.S. Historical Climate Network ( $\mathrm{HCN})$ temperature data found a decreasing and increasing trend in growingseason mean maximum temperature for the irrigated and nonirrigated areas, respectively (Mahmood et al. 2004). For example, at York, growing-season mean maximum temperature decreased at the rate of $-0.01^{\circ} \mathrm{C} \mathrm{yr}^{-1}$ (not shown here) while at Halsey it increased at the rate of $+0.01^{\circ} \mathrm{C} \mathrm{yr}^{-1}$ (not shown here). Analyses of data from individual months suggest July and August experienced the greatest rate of decrease in mean maximum temperatures for all irrigated locations (Mahmood et al. 2004). The availability of water and the elevated thermal and radiative condition in July and August provide a suitable environment for a higher evapotranspiration rate and subsequent reduction of mean maximum temperatures (Mahmood et al. 2004). In a follow-up study, Mahmood et al. (2008, manuscript submitted to Climatic Change) found that in some cases up to $1.41^{\circ} \mathrm{C}$ cooling has occurred over irrigated areas during growing season. This study also suggested that this cooling is related to an increase in the energy partitioned to latent heat of evaporation and thus an increase in atmospheric water vapor. Increase in $T_{d}$ over irrigated areas present direct evidence of previous findings.

McPherson et al. (2004) found a cool anomaly of mean maximum temperature over the Oklahoma wheat belt during the growing season. Their study reported higher daily maximum dewpoint temperature over the wheat belt in March and April. These months coincide with the maximum growth period for the winter wheat. In addition, compared to its surrounding areas, a relatively lower vapor pressure deficit was found over the Oklahoma winter wheat belt during its growing period (McPherson et al. 2004). Hence, higher $T_{d}$ over irrigated areas during the growing season agrees with the McPherson et al. (2004) finding.

Kalnay and Cai (2003) suggested that agricultural expansion would increase daytime evaporation and result in decreasing maximum temperature. Christy et al. (2006) investigated the impacts of irrigation in central California and reported a slightly negative trend in monthly maximum temperature for this time period. They have suggested increased evaporation resulted in lowering of maximum temperature. Therefore, the trend analyses by Kalnay and Cai (2003) and Christy et al. (2006) agree with the underlying context of this study.

Significant land use change has occurred over other parts of the world. Many regions have experienced introduction of widespread irrigated agriculture. The authors of this study suggest that impacts of these changes on $T_{d}$ along with air temperature need to be investigated. It is proposed that the climate change framework should be inclusive of the land use change issue in the context of its impacts on the atmospheric system.

Acknowledgments. This study is partly funded by NOAA Contract EA 133E-02-CN-0025. The authors thank two reviewers for valuable comments and suggestions that helped to improve this manuscript. Thanks also are given to Shawn M. Simpson and Ashley Littell for preparation of Fig. 2.

\section{REFERENCES}

Adegoke, J. O., R. A. Pielke Sr., J. Eastman, R. Mahmood, and K. G. Hubbard, 2003: A regional atmospheric model study of the impact of irrigation on midsummer surface energy budget in the U.S. High Plains. Mon. Wea. Rev., 131, 556-564.

Allen, R. G., M. Smith, L. S. Pereira, and A. Perrier, 1994: An update for the calculation of reference evapotranspiration. ICID Bull., 43, 35-92.

Bonan, G., 1997: Effects of land use on the climate of the United States. Climatic Change, 37, 449-486.

_ 2001: Observational evidence for reduction of daily maximum temperature by croplands in the Midwest United States. J. Climate, 14, 2430-2442.

Chase, T. N., T. G. F. Kittel, J. S. Baron, and T. J. Stohlgren, 1999: Potential impacts on Colorado Rocky Mountain weather due to land use changes on the adjacent Great Plains. J. Geophys. Res., 104, $16673-16690$.

Christy, J. R., W. B. Norris, K. Redmond, and K. Gallo, 2006: Methodology and results of calculating central California surface temperature trends: Evidence of human-induced climate change? J. Climate, 19, 548-563.

Eastman, J. L., M. B. Coughenour, and R. A. Pielke Sr., 2001: The regional effects of $\mathrm{CO}_{2}$ and landscape change using a coupled plant and meteorological model. Global Change Biol., 7, 797815.

Geerts, B., 2002: On the effects of irrigation and urbanisation on the annual range of monthly-mean temperatures. Theor. Appl. Climatol., 72, 157-163.

Kalnay, E., and M. Cai, 2003: Impact of urbanization and land use change. Nature, 423, 528-531.

Mahmood, R., and K. G. Hubbard, 2002: Anthropogenic land use change in the North American tall grass-short grass transition and modification of near surface hydrologic cycle. Climate Res., 21, 83-90.

,-- , and Q. Hou, 2001: Soil moisture monitoring and modeling in the Great Plains. Automated Weather Stations for Applications in Agriculture and Water Resources Management: Current Use and Future Perspectives, K. G. Hubbard and M. V. K. Sivakumar, Eds., High Plains Climate Center and World Meteorological Organization, 163-171.

- — - and C. Carlson, 2002: Land use change and modification of near-surface thermal records in the northern Great Plains. Bull. Amer. Meteor. Soc., 83, 504.

,$- \ldots$, and,- 2004 : Modification of growing-season sur- 
face temperature records in the northern Great Plains due to land use transformation: Verification of modeling results and implications for global climate change. Int. J. Climatol., 24, 311-327.

McPherson, R. A., D. J. Stensrud, and K. C. Crawford, 2004: The impact of Oklahoma's wheat belt on the mesoscale environment. Mon. Wea. Rev., 132, 405-421.

Murray, F. W., 1967: On the computation of saturation vapor pressure. J. Appl. Meteor., 6, 203-204.
Sandstrom, M. A., R. G. Lauritsen, and D. Changnon, 2004: A central U.S. summer extreme dew-point climatology (19492000). Phys. Geogr., 25, 191-207.

University of Nebraska-Lincoln (UNL), 2000: Center-Pivot Irrigation Systems in Nebraska, 1997.

Waisenan, P. J., and N. B. Bliss, 2002: Changes in population and agricultural land in conterminous United States, 1790 to 1997. Global Biogeochem. Cycles, 16, 1137, doi:10.1029/ $2001 \mathrm{~GB} 001843$. 